Fishes Known to Inhabit the Seas and Freshwaters of India, Burma and Ceylon. Vol. 1, 1967 reprint by Today and Tomorrows Book Agency, New Delhi, 778pp.

Day, F. (1889). The Fauna of British India including Ceylon and Burma, Vol. 1 and 2, Taylor and Francis, London, 548pp.

Hora, S.L. (1942a). Notes on the fishes in the Indian Museum, on the systematic position of Indian species of Scaphiodon Heckel. Records of Indian Museum 44: 1-14.

Hora, S.L. (1942b). A list of fishes of the Mysore State and the neighbouring hills of the Nilgiris, Wynaad and Coorg. Records of Indian Museum 44: 193-200

Hora, S.L. and K.S. Misra (1942). Fishes of Poona, part II. Journal of the Bombay Natural History Society 43: 218-225.

Jayaram, K.C. (1999). The Freshwater Fishes of the Indian Region. Narendra Publishing House, New Delhi, 551pp.

Kalwar, A.G. and C.N. Kelkar (1956). Fishes of Kolhapur. Journal of the Bombay Natural History Society 53: 669-679.

Menon, A.G.K. (1999). Checklist: Freshwater Fishes of India. Records of Zoological Survey of India, Occasional Paper 175, 366p.

Singh, D.F. (1990). Ichthyofauna of Maharshtra - Dhulia District. Records of Zoological Survey of India 86: 83-90.

Sykes, W.H. (1841). On the fishes of Dukhun. Transactions of Zoological Society, London 2: 349-376.

Talwar, P.K. and A.G. Jhingran (1991). Inland Fishes of India and Adjacent Countries. Oxford and IBH Publishing Company Pvt. Ltd., New Delhi, Vol 1, 541pp.

Tilak, R and D.N. Tiwari (1976). On the fish fauna of Poona district, M.S. Newlsletter, Zoological Survey of India 2: 193-199.

Yazdani,G.M. and A.S. Mahabal (1976). Fishes of Indrayani River. Biovigyanum 2: 119-121.

\section{INSECT CONSERVATION - A REACTION TO NARENDRAN AND CHERIAN}

\author{
Rashmi Saxena
}

Assistant Professor of Zoology, Bhupal Nobles' College, Udaipur, Rajasthan 313001, India

Narendran and Cherian (2002) have vividly brought out the great survival capacity of the group Insects. Man's "war" against harmful insects has led only to partial and often to doubtful success. I fully agree with these authors on that insect taxonomy cannot be learnt unless students themselves collect, preserve and identify insects. For higher studies on insect taxonomy, physiology etc. too insect collection is an absolute necessity. Collection of a small number of insect specimens for scientific study should not be a worth considering negative factor, when aiming at insect conservation.

But it has to be accepted that insect species are fast facing extinction. As E.O. Wilson has pointed out the present rate of extinction of invertebrates has become 1000 to 10,000 times greater due to human intervention. Narendran and Cherian have rightly pointed out that insect extinction is mostly due to habitat destruction. To become familiar with habits and habitat of insect species and preventing habitat destruction would be the effective way for insect conservation.

Much of insect fauna however remains to be discovered and described. Even for most of those insects, which have been described, classified and named, habitat and biology details are not known. To get acquainted with biology of most insect species will take a very long drawn out concerted effort by any country's entomologists. Meanwhile much of biodiversity through insects will be wiped out. A practical step to prevent this loss is that small patches of land with different habitats be set aside as reserves, which should be free from human activity. This step for invertebrate conservation have been suggested by Verma (1995) and Verma and Saxena (1996).

It may be emphasised again that ban on or discouraging insect collection for scientific study will not help insect conservation. On the other hand such steps may hamper conservation.

\section{References}

Narendran, T.C. and P.T. Cherian (2002). On some misconceptions on conservation of insects. Zoos' Print Journal 17(1): 687-688.

Verma, K.K. (1995). Strategy for invertebrate conservation Zoos' Print 10 (10): 4

Verma, K.K. and R. Sexena (1996). Invertebrate conservation. Zoos' Print 11(10): 6 and 13. 